Article

\title{
Spatial Distributions, Pollution Assessment, and Qualified Source Apportionment of Soil Heavy Metals in a Typical Mineral Mining City in China
}

\author{
Li Hua, Xue Yang, Yajun Liu, Xiuli Tan and Yong Yang * \\ College of Resources \& Environment, Huazhong Agricultural University, Wuhan 430070, China; \\ huali@mail.hzau.edu.cn (L.H.); hzau_yx@163.com (X.Y.); liuyj@webmail.hzau.edu.cn (Y.L.); \\ tanxl@webmail.hzau.edu.cn (X.T.) \\ * Correspondence: yangyong@mail.hzau.edu.cn; Tel.: +86-27-87281181; Fax: +86-27-87396057
}

Received: 23 July 2018; Accepted: 24 August 2018; Published: 31 August 2018

\begin{abstract}
Daye is a city in China known for its rich mineral resources, with a history of metal mining and smelting that dates back more than 3000 years. To analyze the spatial distribution patterns, ecological risk, and sources of heavy metals $(\mathrm{Cd}, \mathrm{Co}, \mathrm{Cr}, \mathrm{Cu}, \mathrm{Mn}, \mathrm{Ni}, \mathrm{Pb}$, and $\mathrm{Zn}$ ) in soils, 213 topsoil samples were collected in the main urban area of Daye in September 2016. The mean concentrations of $\mathrm{Cd}, \mathrm{Cu}, \mathrm{Pb}$, and $\mathrm{Zn}$ were higher than the corresponding background values, with the mean concentration of $\mathrm{Cd}$ being almost seven times its background value. Spatially, the high concentrations of $\mathrm{Cd}, \mathrm{Mn}, \mathrm{Pb}$, and $\mathrm{Zn}$ were mainly concentrated in the southeastern part of the region due to nonferrous metal mining and smelting. However, the high concentrations of $\mathrm{Co}$ and $\mathrm{Cu}$ were concentrated in the central part of the study area, resulted from copper mining and smelting. The data of the geoaccumulation index showed that the contamination levels ranged from no pollution $(\mathrm{Co}, \mathrm{Cr}$, $\mathrm{Mn}$, and $\mathrm{Ni}$ ) to heavy contamination $(\mathrm{Cd}, \mathrm{Cu}$, and $\mathrm{Pb})$. Ecological risk assessment showed that $\mathrm{Cd}$ posed a high, serious, and even severe ecological risk in 53.78\% of the area of Daye. According to the results of the principal component analysis, mineral exploitation and smelting involving a variety of minerals (ES_M), mining exploitation, and smelting of copper ore (ES_C), and natural sources are the three main sources of heavy metals in these soils. Furthermore, the absolute principal component scores showed that $69.21 \%$ and $23.17 \%$ of the heavy metal concentrations were ascribed to ES_M and ES_C, respectively.
\end{abstract}

Keywords: soil; heavy metal; PCA/APCS; potential ecological risk; geoaccumulation index

\section{Introduction}

With the increases in intense urbanization, industrialization, and human population, soil heavy metal pollution has been significant over the past several decades because of the toxicity and undegradability of these pollutants [1-4]. Many studies have shown that the accumulation of heavy metals in the soil degrades the quality of farmland, food crops, and humans' living environment and threatens human health via the food chain or dermal contact $[5,6]$.

In China, there are 171 varieties of mineral resources, and the proven reserves of mineral resources in China constitute $12 \%$ of the total mineral resources in the world [7]. Existing studies have shown that heavy metal soil pollution is related to mining activities, including mining, smelting, and transportation. For example, Liang et al. reported that $26.05 \%$ of the heavy metals in soil were a result of mining activities in a typical coal mining city, Lianyuan, in the Hunan province of China [8]. Wang et al. reported that $65.7 \%$ of soil samples taken near a tungsten mine in the Dayu County of Jiangxi province, China, were polluted with heavy metals [9]. Xu et al. investigated paddy soils from lead-zinc mining 
areas in the Guangdong province, China [10]. Their results indicated that the paddy soils were heavily contaminated with $\mathrm{Cd}, \mathrm{Pb}$, and $\mathrm{Zn}$ in amounts that exceeded the corresponding soil quality standard values and background values.

The city of Daye in the Hubei province, China, is known for its mining activities, with rich mineral resources and a history of metal mining and smelting of more than 3000 years. There are 65 kinds of minerals exploited in Daye, with 273 deposits and 42 kinds of mineral deposits in the reserves. In previous studies, some soil heavy metals, such as $\mathrm{Cd}, \mathrm{Pb}$, and $\mathrm{Zn}$, were investigated and assessed in a small part of Daye, and serious contamination with $C d$ was found [11,12]. Meanwhile, some studies investigated and assessed the heavy metals pollution in agricultural soils of Daye indicated that As, $\mathrm{Cd}, \mathrm{Cu}$, and $\mathrm{Zn}$ were indicators of anthropic pollution $[13,14]$. Then, the high concentrations of those heavy metals in farmland soil lead to pollution risks of crops and foods $[15,16]$. However, the mines and related smelters in Daye are in close proximity to residential, commercial, and agricultural areas. Additionally, the existing studies paid more attention to farmland soil around Daye city, or the soil in a small area around a mining area. Thus, a comprehensive pollution assessment of the mining areas in Daye is urgently needed.

Furthermore, in the existing studies about regional soil heavy metals, pollution assessment, risk assessment, spatial distribution analysis, and source apportionment analysis of heavy metals were carried out based on surface soil samples. The spatial distributions generated by spatial prediction methods (e.g., various Kriging methods) reveal the spatial characteristics or patterns of soil heavy metals. However, the pollution assessment, risk assessment, and source apportionment of heavy metals performed in most of these studies were based on soil sample data rather than on the spatial distributions of heavy metals. That is, the objects of pollution assessment, risk assessment, and source apportionment were only the soil samples, and all calculations were based on the heavy metals concentrations of those soil samples. This will lead to a unilateral understanding of the regional soil pollution only in the area where the soil samples are located. Thus, it is difficult to fully understand and assess the severity of heavy metal pollution in the soils of this region. Moreover, it is impossible to quantify the contributions of each identified source to the pollution in each location of the study area.

Based on the facts discussed above, the primary objectives of this study were to (1) determine the spatial distributions of soil heavy metal concentrations, (2) assess the heavy metal contamination in soil based on the above spatial maps, and (3) quantify the source apportionment of regional soil heavy metal concentrations, and express the contributions of each identified source at each location in the study area. The results of this study can help local governments understand, control, and manage regional heavy metal soil pollution.

\section{Materials and Methods}

\subsection{Study Area and Data}

The city of Daye (latitude $29^{\circ} 40^{\prime}-30^{\circ} 15^{\prime} \mathrm{N}$, longitude $114^{\circ} 31^{\prime}-115^{\circ} 20^{\prime}$ E) is located in the southeastern area of the Hubei province along the south bank of the middle reaches of the Yangtze River. Due to its rich mineral resources, there are still numerous mines (coal, copper, iron, and gold) and smelting factories around Daye. To assess the soil heavy metal pollution, a total of 213 topsoil samples were collected in the main urban area of Daye during September 2016. The sampling points were randomly distributed in the study area based on a regular grid of $0.7 \times 0.7 \mathrm{~km}$, and each grid had at least one sampling point. The topsoil $(0-20 \mathrm{~cm})$ was collected by mixing 5 sub-samples obtained in different directions using a stainless steel hand spade. The spatial site of each sampling point was recorded using a hand-held positioning system (GPS). All soil samples were air-dried at room temperature, then passed through a $0.15 \mathrm{~mm}$ nylon sieve. These fine fractions were digested using a ternary mixture of concentrated acids consisting of $6 \mathrm{ml} \mathrm{HCO}_{4}, 5 \mathrm{~mL} \mathrm{HF}$, and $3 \mathrm{~mL} \mathrm{HNO}_{3}$ [17]. The concentrations of eight heavy metal elements ( $\mathrm{Cd}, \mathrm{Co}, \mathrm{Cr}, \mathrm{Cu}, \mathrm{Mn}, \mathrm{Ni}, \mathrm{Pb}$, and $\mathrm{Zn}$ ) were measured using inductively coupled plasma mass spectrometry (ICP-MS). Quality assurance and quality control for metals in 
soils sample were carried out by the $20 \%$ analysis (in duplicate) of randomly chosen samples and was found to be within the accepted standard reference materials (GSS-3), which were obtained from the Center of National Standard Reference Material of China. The results were considered acceptable when the coefficients of variation were within $5 \%$. All soil samples were analyzed at the Key Laboratory of Arable Land Conservation (middle and lower reaches of the Yangtze River), Chinese Ministry of Agriculture, Wuhan city. Land cover data were obtained by visual interpretation of contemporaneous Google remote sensing data. As shown in Figure 1, the mines are distributed throughout the southern and northern portions of the mountain forest area; some mineral smelters are distributed on the edge of the urban area; the factories, including those for mechanical and electrical manufacturing, textiles, clothing, electronics, new materials, and food and beverages, are located in the northern portion of the study area. The spatial distributions of soil sampling points and land cover are shown in Figure 1.

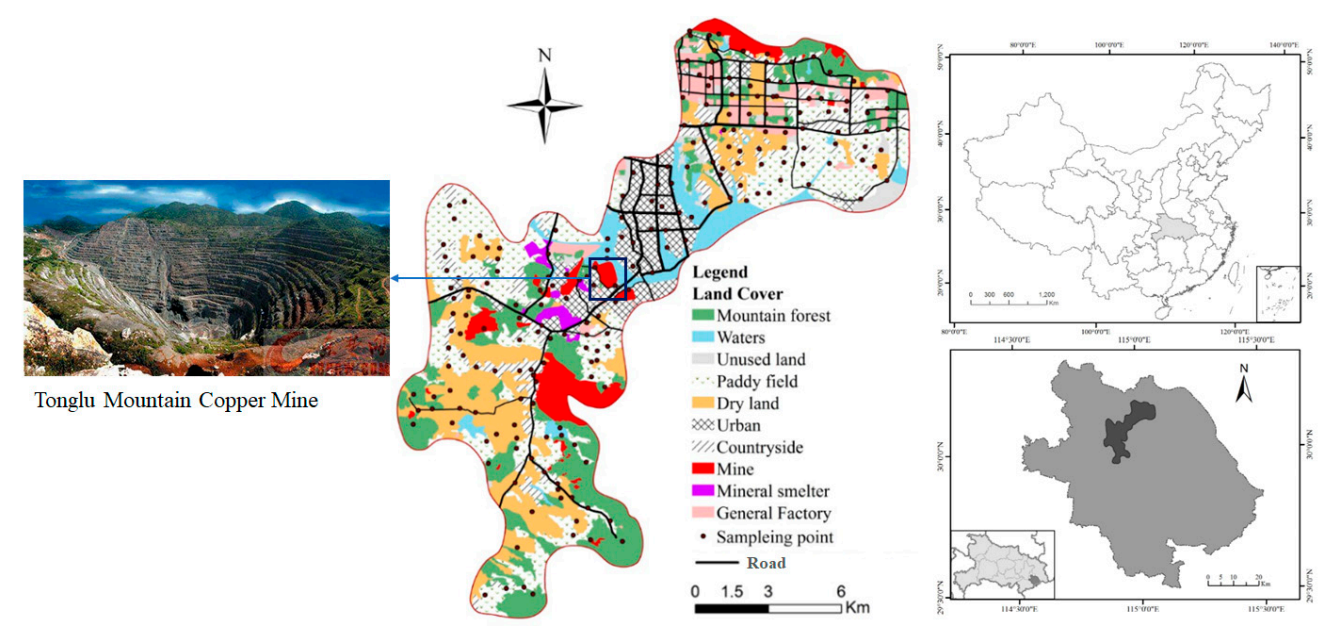

Figure 1. Map of soil sampling sites and land cover in main urban area of Daye.

\subsection{Data Analysis and Spatial Distribution Maps}

Standard statistical analysis was carried out to describe the soil heavy metal concentrations using Excel software (Version 14, Microsoft, Inc., Redmond, Washington, DC, USA). Then, Pearson correlation analysis based on sampling points was used as an indicator of the relationships between different heavy metals in soils using IBM SPSS Statistics software (Version 19.0, Armonk, NY, USA). Ordinary Kriging (OK) interpolation was performed on the concentrations of soil heavy metals using ArcGIS software (Version 10.2, ESRI, Inc., Redlands, CA, USA). The standard sample-based cross-validation technique was implemented to assess the spatial interpolation accuracy. Based on the leave one-out cross validation technique, two accuracy indicators were computed from the pairs of "estimated-observed" soil heavy metal concentrations at the sampling points: The Pearson correlation coefficient $(r)$ and the mean absolute error (MAE). The $r$ and MAE were used to measure the strength of the linear relation and mean absolute deviation between the estimated and the observed soil heavy metal concentrations, respectively. For an accurate spatial interpolation, $r$ should be close to 1 , and the MAE should be as small as possible. In addition, to remove any quantitative differences among the various heavy metals in the soils, an error rate (ER) was defined as the ratio of the MAE over the mean value of the heavy metals.

\subsection{Methods for the Assessment of Pollution and Potential Ecological Risk}

The geoaccumulation index $\left(I_{g e o}\right)$ was used to assess metal contamination levels because $I_{g e o}$ is the most popular index for pollution evaluation based on single heavy metals in soils [18]; $I_{\text {geo }}$ is defined as follows [19]:

$$
I_{\text {geo }}=\log _{2}\left(C_{n} / 1.5 B_{n}\right)
$$


where $C_{n}$ and $B_{n}$ are the concentration of heavy metal, $n$, in the soil and the geochemical background concentration of the corresponding heavy metal, $n$, respectively, in the Hubei province. Unlike calculations in previous studies, $I_{g e o}$ was calculated based on the spatial distribution of various heavy metals instead of the concentrations in soil samples. That is, $I_{g e o}$ was determined for each heavy metal at each location, and the overall picture of heavy metal pollution in the study area can be obtained in the present study. Based on the $I_{g e o}$ value for each heavy metal, the heavy metal pollution was classified into 7 categories: $I_{\text {geo }} \leq 0$ (practically uncontaminated), $0<I_{\text {geo }} \leq 1$ (uncontaminated to moderately contaminated), $1<I_{\text {geo }} \leq 2$ (moderately contaminated), $2<I_{\text {geo }} \leq 3$ (moderately to heavily contaminated), $3<I_{\text {geo }} \leq 4$ (heavily contaminated), $4<I_{\text {geo }} \leq 5$ (heavily to extremely contaminated), and $I_{\text {geo }}>5$ (extremely contaminated).

The potential ecological risk index (RI) was used to quantitatively express the potential ecological risk posed by a variety of toxic heavy metals. The RI is calculated by the following formulas [20,21]:

$$
\mathrm{RI}=\sum_{i=1}^{n} E_{i}=\sum_{i=1}^{n} T_{i} \times C_{f}^{i}=\sum_{i=1}^{n} T_{i} \times \frac{C_{i}}{C_{0}}
$$

where $E_{i}$ is the potential ecological risk factor for a given heavy metal, $i, T_{i}$ is the toxic coefficient of a heavy metal, $i, C_{i}$ is the concentration of the heavy metal, and $C_{0}$ is the background value of the corresponding heavy metal in the Hubei province. Based on previously published research, the toxic coefficients of $\mathrm{Cd}, \mathrm{Co}, \mathrm{Cr}, \mathrm{Cu}, \mathrm{Mn}, \mathrm{Ni}, \mathrm{Pb}$, and $\mathrm{Zn}$ are 30, 5, 2, 5, 1, 5, 5, and 1, respectively [22]. Based on $E_{i}$ or the RI, the potential ecological hazard posed by heavy metals was classified into 5 grades (see Table 1). The calculations introduced in this section were completed using Excel software (Version 14, Microsoft Inc., Redmond, Washington, DC, USA).

Table 1. Criteria of the potential ecological risk hazard for $E_{i}$ or the ecological risk index (RI).

\begin{tabular}{cccc}
\hline Values of $\boldsymbol{E}_{\boldsymbol{i}}$ & Grades & Values of the RI & Grades \\
\hline$E_{i}<40$ & Low & $\mathrm{RI}<150$ & Low \\
$40 \leq E_{i}<80$ & Moderate & $150 \leq \mathrm{RI}<300$ & Moderate \\
$80 \leq E_{i}<160$ & High & $300 \leq \mathrm{RI}<600$ & High \\
$160 \leq E_{i}<320$ & Serious & $\mathrm{RI} \geq 600$ & Serious \\
$E_{i} \geq 320$ & Severe & $/$ & $/$ \\
\hline
\end{tabular}

\subsection{Principal Component Analysis (Pca) and Absolute Principal Component Scores (APCS)}

PCA/APCS is an effective multivariate factor analysis model for the identification of pollution sources. It was first applied to estimate sources of particulate matter in Boston by Thurston and Spengler [23]. The PCA/APCS receptor model can quantitatively determine not only the load of each pollutant attributed to each source, but also the average contribution of each source to each pollutant and to the pollution in each sample. Currently, the model is mainly used in research on air pollution and water pollution [24-27]. In this study, PCA was performed on the spatial distributions of heavy metal accumulation in soils for source identification using factor extraction with eigenvalues $>1$ after varimax rotation. Then, APCS were used to estimate the source contributions to each heavy metal in the following steps:

Step 1: The first step of determining APCS is the normalization of all heavy metal accumulation values as $Z_{i k}$ using the following equation:

$$
Z_{i k}=\left(A_{i k}-\bar{A}_{i}\right) / \sigma_{i}
$$

where $A_{i k}$ is the accumulation of the heavy metal, $i$, at the location, $k$, and $\bar{A}_{i}$ and $\sigma_{i}$ are its mean value and standard deviation, respectively; 
Step 2: By introducing an artificial sample, with accumulations equal to zero for all heavy metals, the true zero for each factor score is calculated:

$$
\left(Z_{0}\right)_{i}=\frac{\left(0-C_{i}\right)}{\sigma_{i}}=-\frac{C_{i}}{\sigma_{i}}
$$

Step 3: The factor scores of those normalized heavy metal accumulation values are obtained by the PCA method. The APCS of each heavy metal at each location are obtained by subtracting the factor scores for this artificial sample from the factor scores of each location; and

Step 4: The source contributions are derived by regression using the following equation:

$$
A_{i}=\left(b_{0}\right)_{i}+\sum_{p=1}^{n} A P C S_{p} \times b_{p i}
$$

where $A_{i}$ is the accumulation of the heavy metal, $i,\left(b_{0}\right)_{i}$ is the constant term of multiple regression for the heavy metal, $i, b_{p i}$ is the coefficient of multiple regression of the source, $p$, for the heavy metal, $i$, and $A P C S_{p}$ is the scaled value of the rotated factor, $p$, for the considered location. $A P C S_{p} \times b_{p i}$ is the contribution of the source, $p$, to $A_{i}$. The mean of the product, $A P C S_{p} \times b_{p i}$, at all locations represents the average contribution of the sources. The calculations introduced in this section were completed using SPSS software (Version 19.0 for Windows, IBM Inc., Armonk, NY, USA) and Excel software (Version 14, Microsoft Inc., Redmond, WA, USA).

\section{Results and Discussion}

\subsection{Descriptive Statistics and Spatial Distributions of Soil Heavy Metals}

Based on the available samples, the statistical characteristics of the heavy metal concentrations in the Daye region are presented in Table 2. As shown in Table 2, the percentage of sampling points where the concentration exceeds the background $(\mathrm{PbB})$ was greater than $50 \%$ for $\mathrm{Cd}, \mathrm{Cu}, \mathrm{Pb}$, and $\mathrm{Zn}$, indicating serious $\mathrm{Cd}, \mathrm{Cu}, \mathrm{Pb}$, and $\mathrm{Zn}$ pollution in the study area. On the other hand, although the mean concentrations of $\mathrm{Co}$ and $\mathrm{Mn}$ were less than their background values, their $\mathrm{PbB}$ values exceeded $30 \%$, indicating that part of the study area was polluted by these two heavy metals.

Table 2. Descriptive statistics of the heavy metals in the soils of the study area (mg/kg).

\begin{tabular}{ccccccccc}
\hline $\begin{array}{c}\text { Heavy } \\
\text { Metal }\end{array}$ & Min & Max & Mean & Median & SD & CV & BGV & PbB \\
\hline $\mathrm{Cd}$ & 0.03 & 34.63 & 1.14 & 0.47 & 3.13 & 2.75 & 0.17 & $76.06 \%$ \\
$\mathrm{Co}$ & 5.13 & 76.89 & 14.65 & 13.79 & 6.00 & 0.41 & 15.40 & $30.52 \%$ \\
$\mathrm{Cr}$ & 8.62 & 117.02 & 35.54 & 33.96 & 14.60 & 0.41 & 86.00 & $0.94 \%$ \\
$\mathrm{Cu}$ & 9.37 & 2056.64 & 175.45 & 65.69 & 330.18 & 1.88 & 30.70 & $85.45 \%$ \\
$\mathrm{Mn}$ & 115.64 & 2173.26 & 672.26 & 572.71 & 358.20 & 0.53 & 712.00 & $33.80 \%$ \\
$\mathrm{Ni}$ & 3.82 & 83.28 & 28.14 & 26.65 & 10.83 & 0.38 & 37.30 & $13.15 \%$ \\
$\mathrm{~Pb}$ & 0.10 & 3906.67 & 102.77 & 28.25 & 335.59 & 3.27 & 26.70 & $52.20 \%$ \\
$\mathrm{Zn}$ & 48.91 & 2578.65 & 256.73 & 191.00 & 234.18 & 0.91 & 83.60 & $98.12 \%$ \\
\hline
\end{tabular}

SD: Standard deviation; CV: Coefficient of variation; BGV: Background values at the provincial level from the report, "The Background Concentrations of Soil Elements of China" [28]. PbB: Percentage of sampling points above the BGV.

The heavy metals in soils were also studied in different mines in China. As shown in Table 3, the concentration distribution patterns of $\mathrm{Cd}$ in this study were similar to the values found in the Nandan County, which is located in the north of the Guangxi province as a mining town [29]. However, the mean concentration of $\mathrm{Cd}$ was much lower than those reported from some large lead-zinc mining areas, such as the lead-zinc mine in Qixiashang of Nanjing city with a mean of $17.56 \mathrm{mg} / \mathrm{kg}$ [30], and the lead-zinc mine with a mean of $15.56 \mathrm{mg} / \mathrm{kg}$ in the Lanping county, Yunnan province, China [31]. 
Compared to soil from other mining areas, the mean value of $\mathrm{Cu}$ in Daye soils was markedly three to six times higher than the values reported in other urban soils [8,31-34]. However, the mean value of $\mathrm{Cu}$ was still lower than the value in soils of the mining area in Nanjing city [30,35]. The measured mean values of $\mathrm{Mn}, \mathrm{Pb}$, and $\mathrm{Zn}$ were extremely higher in the soils of lead-zinc or $\mathrm{Mn}$ mining areas than the values presented in this study. For example, the mean concentrations of $\mathrm{Mn}, \mathrm{Pb}$, and $\mathrm{Zn}$ were $14015.31 \mathrm{mg} / \mathrm{kg}, 2232.16 \mathrm{mg} / \mathrm{kg}$, and $5201.86 \mathrm{mg} / \mathrm{kg}$, respectively, in the soils of the lead-zinc mine of Nanjing city [35]. The mean values of $\mathrm{Pb}$ and $\mathrm{Zn}$ were $1093.03 \mathrm{mg} / \mathrm{kg}$ and $867.08 \mathrm{mg} / \mathrm{kg}$, respectively, in the soils of a lead-zinc mine in the Guangdong province [10]. The mean concentrations of $\mathrm{Mn}, \mathrm{Pb}$, and $\mathrm{Zn}$ were $8853.21 \mathrm{mg} / \mathrm{kg}, 1211.29 \mathrm{mg} / \mathrm{kg}$, and $685.36 \mathrm{mg} / \mathrm{kg}$, respectively, in a Mn mine in Xiangtan city, Hunan province [36]. According to the comparisons above, the mean concentration of $\mathrm{Cu}$ in soils was higher than most of the other mining areas in China. However, the concentrations of $\mathrm{Cd}, \mathrm{Mn}, \mathrm{Pb}$, and $\mathrm{Zn}$ were lower than other mining areas, especially lead-zinc mines, in China. Thus, the concentrations of heavy metals in soils may be closely related to the local mineral type.

The Pearson's correlation coefficients between the concentrations of heavy metals in soils based on sampling points are summarized in Table 4. The concentration of $\mathrm{Cd}, \mathrm{Mn}, \mathrm{Pb}$, and $\mathrm{Zn}$ showed a high significant positive relationship with each other, which may suggest a common origin. The correlation coefficient between $\mathrm{Cu}$ and $\mathrm{Co}$ is 0.62 , indicating a common source. Additionally, the correlation coefficient between $\mathrm{Cu}$ and $\mathrm{Co}$ is 0.51 , also suggesting a common origin. Furthermore, although there are some other significant positive relationships, such as $\mathrm{Cr}$ and $\mathrm{Cd}, \mathrm{Mn}$ and $\mathrm{Cr}$, $\mathrm{Zn}$ and $\mathrm{Co}$, and so on, the correlation coefficients between them are not high. Thus, the results of the correlation analysis based on the sampling points cannot clearly indicate the sources of pollution.

The spatial distributions of the $\mathrm{Cd}, \mathrm{Co}, \mathrm{Cr}, \mathrm{Cu}, \mathrm{Mn}, \mathrm{Ni}, \mathrm{Pb}$, and $\mathrm{Zn}$ concentrations in the study area are presented in Figure 2. To intuitively understand the severity of the heavy metal pollution levels in the soil of the Daye region, in the maps of Figure 2, the yellow, blue, and red colors represent heavy metal concentrations that are close to, lower than, and higher than their background values, respectively. As shown in Figure 2, the maps of the $\mathrm{Cd}, \mathrm{Cu}, \mathrm{Pb}$, and $\mathrm{Zn}$ distributions are almost entirely covered with red and yellow colors, indicating that the concentrations of these four heavy metals were higher than their background values over almost the entire study region. Regarding the $\mathrm{Cr}$ and $\mathrm{Ni}$ maps, most of the study region was covered in blue, indicating that only a small part of the region was polluted with $\mathrm{Cr}$ and Ni. Based on the Co and Mn maps, it was concluded that nearly half of the study region was polluted with these elements. Furthermore, the spatial distribution patterns of all heavy metals were characterized by decreasing concentrations from the central and southeastern parts toward the southern and northern parts. These concentrations peaked in the central and southeastern part, which may be related to the mining and smelting operations in that region (see Figure 1). 
Table 3. Heavy metal concentrations in soils from different mines in China (mg/kg).

\begin{tabular}{|c|c|c|c|c|c|c|c|c|c|c|}
\hline Area & Mine Type & Reference & $\mathrm{Cd}$ & Co & $\mathrm{Cr}$ & $\mathrm{Cu}$ & Mn & $\mathrm{Ni}$ & $\mathrm{Pb}$ & $\mathrm{Zn}$ \\
\hline Daye, Hubei province & A variety of nonferrous metals & & 1.14 & 14.65 & 35.54 & 175.45 & 672.26 & 28.14 & 102.77 & 256.73 \\
\hline Nandan, Guangxi province & Lead-Zinc & Tian et al. 2018 & 1.77 & / & / & 57.5 & & & 108 & 312 \\
\hline Qixiashang of Nanjing & Lead-Zinc & Chu et al. 2010 & 17.56 & / & 90.0 & 201.83 & & & 3128.87 & 2873.49 \\
\hline lanping county, Yunnan province & Lead-Zinc & Zhou et al. 2018 & 15.56 & / & 33.4 & 26.1 & / & 14.3 & 419.4 & 933.4 \\
\hline Dexing, Jiangxi province & Copper, coal & Chen et al. 2007 & 0.275 & / & 73.00 & 60.00 & / & / & 51.00 & 112.00 \\
\hline Huize Country, Yunnan province & Lead-Zinc & Lu et al. 2014 & 2.30 & / & 95.60 & 23.50 & / & / & 218.60 & 337.80 \\
\hline Meizhou, Guangdong province & $\mathrm{Ag}-\mathrm{Sb}$ & Liu et al. 2015 & 1.11 & / & 178.82 & 35.34 & l & 92.85 & / & 130.84 \\
\hline Lianyuan, Hunan province & coal & Jie et al. 2017 & 0.59 & / & 93.03 & 33.26 & 552.5 & / & 37.82 & 107.24 \\
\hline Nanjing province & Lead-Zinc & Li et al. 2018 & 45.71 & / & 92.92 & 216.46 & $14,015.3$ & 1 & 2232.16 & 5201.86 \\
\hline Guangdong province & Lead-Zinc & Xu et al. 2017 & 7.04 & / & 30.91 & 57.80 & 358.77 & 20.25 & 1093.03 & 867.08 \\
\hline Xiangtan, Hunan province & Manganese & Xie et al. 2005 & 13.15 & & & 95.80 & 8853.21 & 91.33 & 1211.29 & 685.36 \\
\hline
\end{tabular}

/: Not available.

Table 4. Pearson's correlation matrix for the heavy metals in soils based on sampling points.

\begin{tabular}{|c|c|c|c|c|c|c|c|c|}
\hline & $\mathrm{Cd}$ & Co & $\mathrm{Cr}$ & $\mathrm{Cu}$ & Mn & $\mathrm{Ni}$ & $\mathrm{Pb}$ & $\mathrm{Zn}$ \\
\hline $\mathrm{Cd}$ & 1 & & & & & & & \\
\hline Co & 0.04 & 1 & & & & & & \\
\hline $\mathrm{Cr}$ & $0.17^{*}$ & 0.18 * & 1 & & & & & \\
\hline $\mathrm{Cu}$ & $0.28^{* *}$ & $0.62^{* *}$ & $0.2^{* *}$ & 1 & & & & \\
\hline Mn & $0.43^{* *}$ & $0.32^{* *}$ & $0.2^{* *}$ & $0.32^{* *}$ & 1 & & & \\
\hline $\mathrm{Ni}$ & 0.15 * & $0.26^{* *}$ & $0.51^{* *}$ & 0.06 & $0.24^{* *}$ & 1 & & \\
\hline $\mathrm{Pb}$ & $0.86^{* *}$ & -0.06 & 0.09 & 0.14 * & $0.52^{* *}$ & 0.13 & 1 & \\
\hline $\mathrm{Zn}$ & $0.8^{* *}$ & $0.19^{* *}$ & $0.25^{* *}$ & $0.4^{* *}$ & $0.65^{\text {** }}$ & $0.3^{* *}$ & $0.9^{* *}$ & 1 \\
\hline
\end{tabular}




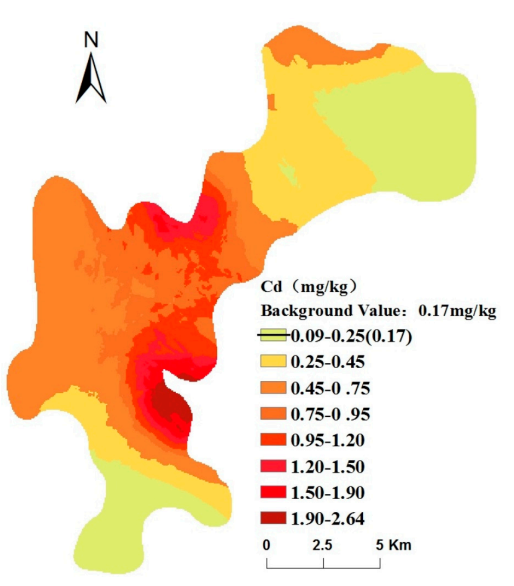

(a)

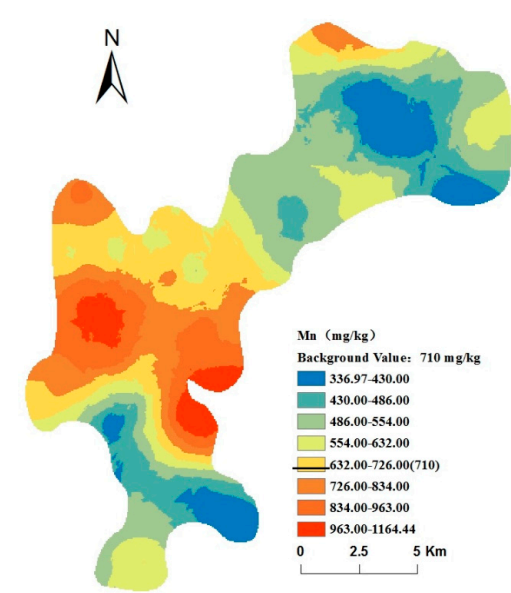

(e)

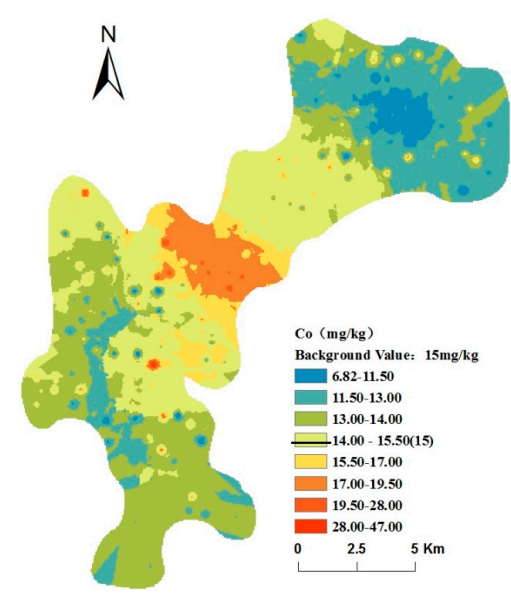

(b)

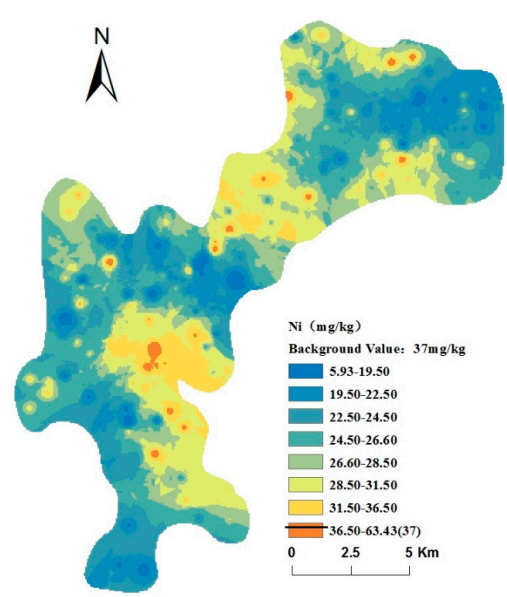

(f)

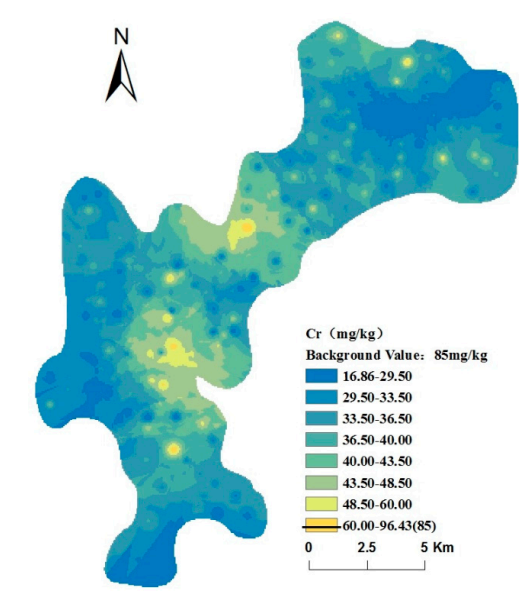

(c)

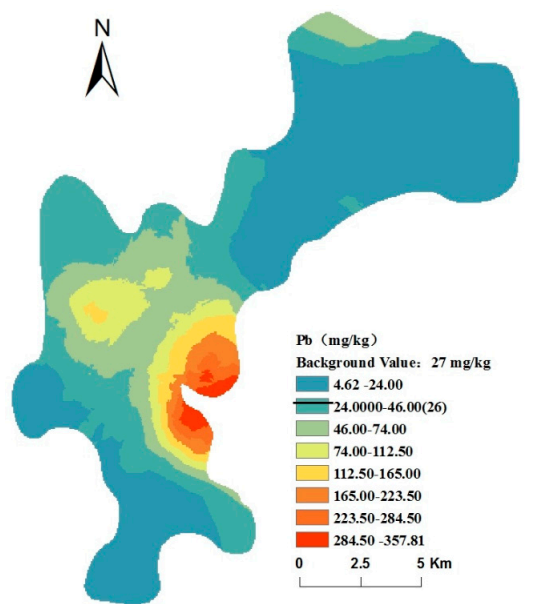

(g)

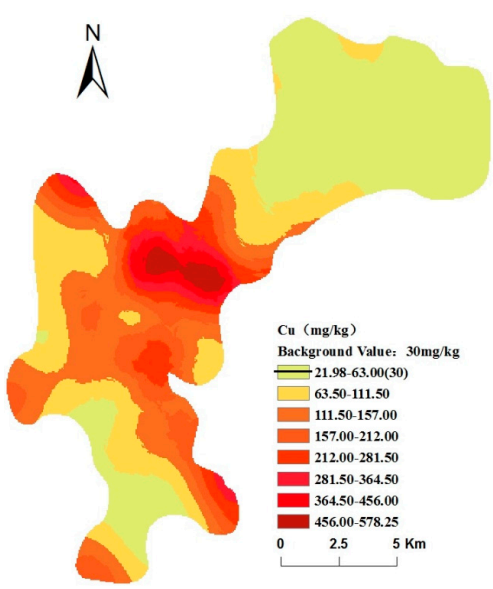

(d)

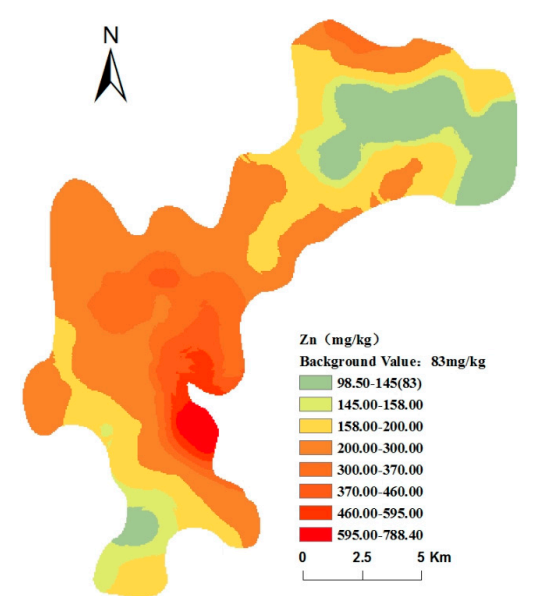

(h)

Figure 2. Spatial distribution maps of (a) $\mathrm{Cd},(\mathbf{b}) \mathrm{Co},(\mathbf{c}) \mathrm{Cr},(\mathbf{d}) \mathrm{Cu},(\mathbf{e}) \mathrm{Mn},(\mathbf{f}) \mathrm{Ni},(\mathbf{g}) \mathrm{Pb}$, and (h) $\mathrm{Zn}$ in the study area (the lines in the legends represent the corresponding background values of heavy metals in soils). 
Table 5 summarizes the cross-validation results for the spatial distributions of heavy metal concentrations obtained by OK interpolation. These results show that the $r$ and ER values of the eight heavy metal concentrations ranged from 0.75 to $0.99(p<0.01)$ and from $4.75 \%$ to $18.42 \%$, respectively, indicating high spatial interpolation accuracy (note the high $r$ and low ER values). Hence, the spatial interpolation results were valuable for subsequent analyses.

Table 5. Results of cross-validation using the spatial interpolation method.

\begin{tabular}{ccccccccc}
\hline Element & $\mathbf{C d}$ & $\mathbf{C o}$ & $\mathbf{C r}$ & $\mathbf{C u}$ & $\mathbf{M n}$ & $\mathbf{N i}$ & $\mathbf{P b}$ & $\mathbf{Z n}$ \\
\hline$r$ & $0.75^{*}$ & $0.98^{*}$ & $0.98^{*}$ & $0.89^{*}$ & $0.83^{*}$ & $0.99 *$ & $0.86^{*}$ & $0.85^{*}$ \\
$\mathrm{MAE}(m g / \mathrm{kg})$ & 0.21 & 0.67 & 2.14 & 28.38 & 102.62 & 1.29 & 13.03 & 32.62 \\
$\mathrm{ER}(\%)$ & 18.42 & 4.57 & 6.02 & 16.18 & 15.26 & 4.58 & 12.68 & 12.71 \\
\hline
\end{tabular}

${ }^{*}$ Correlation is significant at the 0.01 level; MAE: Mean absolute error; ER: Error rate.

\subsection{Pollution and Ecological Risk Assessment}

Obviously, the spatial $I_{g e o}$ distribution pattern of each heavy metal is similar to the spatial pattern of the corresponding heavy metal distribution in soils, as shown in Figure 2. Therefore, it is not necessary to present the $I_{\text {geo }}$ for each heavy metal spatial distribution here. According to the quantitative $I_{\text {geo }}$ results for the eight heavy metals (Figure 3), $74.23 \%, 77.16 \%, 30.46 \%$, and $94.62 \%$ of the study area was contaminated by $\mathrm{Cd}, \mathrm{Cu}, \mathrm{Pb}$, and $\mathrm{Zn}$, respectively, at various pollution levels. Approximately $0.90 \%, 3.82 \%$, and $0.44 \%$ of the study area was heavily contaminated by $\mathrm{Cd}, \mathrm{Cu}$, and $\mathrm{Pb}$, respectively. Additionally, approximately $38.40 \%, 31.72 \%, 6.86 \%$, and $29.09 \%$ of the study area was moderately contaminated by $\mathrm{Cd}, \mathrm{Cu}, \mathrm{Pb}$, and $\mathrm{Zn}$, respectively. These findings demonstrate that the soils of the study area were partially seriously polluted by some heavy metals (e.g., $\mathrm{Cd}, \mathrm{Cu}, \mathrm{Pb}$, and $\mathrm{Zn}$ ).

As shown in Figure 3b, Cd posed a moderate, high, serious, and severe potential ecological risk in approximately $23.30 \%, 36.80 \%, 15.39 \%$, and $1.59 \%$ of the study area, respectively, whereas almost all of the study area was free from ecological risk posed by other heavy metals, especially Co, Cr, Mn, $\mathrm{Ni}$, and $\mathrm{Zn}$. Thus, it can be concluded that the potential ecological hazard due to heavy metals in Daye soils was mostly derived from the accumulation of $\mathrm{Cd}$. As presented in Figure $3 c$, the RI values exceeded 150 throughout the central part of the study area. The spatial distribution pattern of the RI was similar to the pattern of $\mathrm{Cd}$, indicating that the potential ecological hazard due to soil heavy metals was mainly related to $\mathrm{Cd}$ in Daye City.

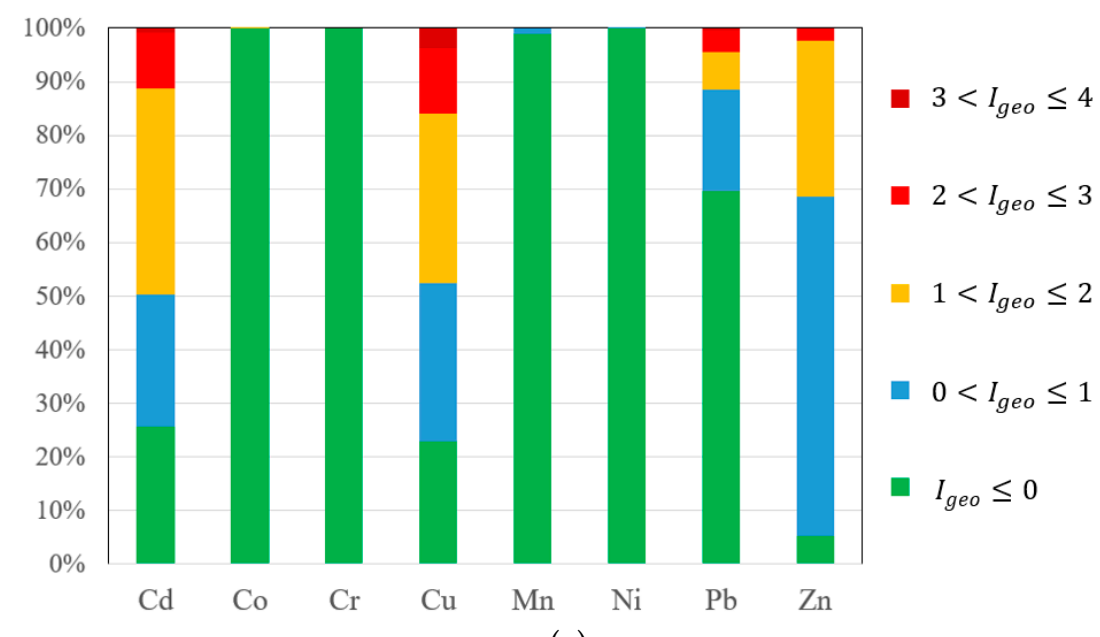

(a)

Figure 3. Cont. 


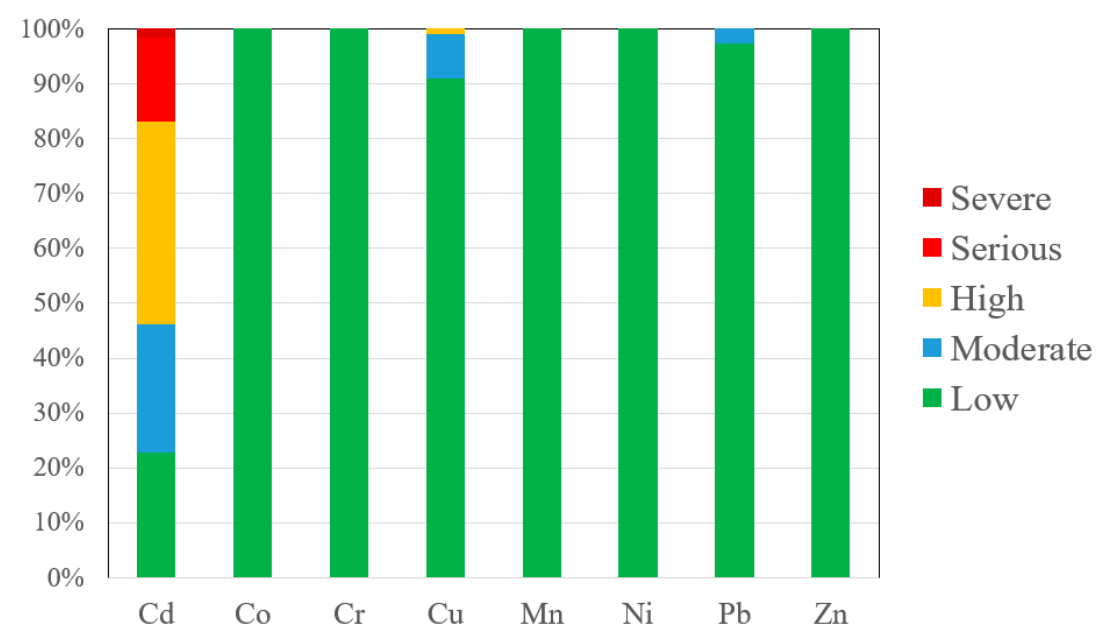

(b)

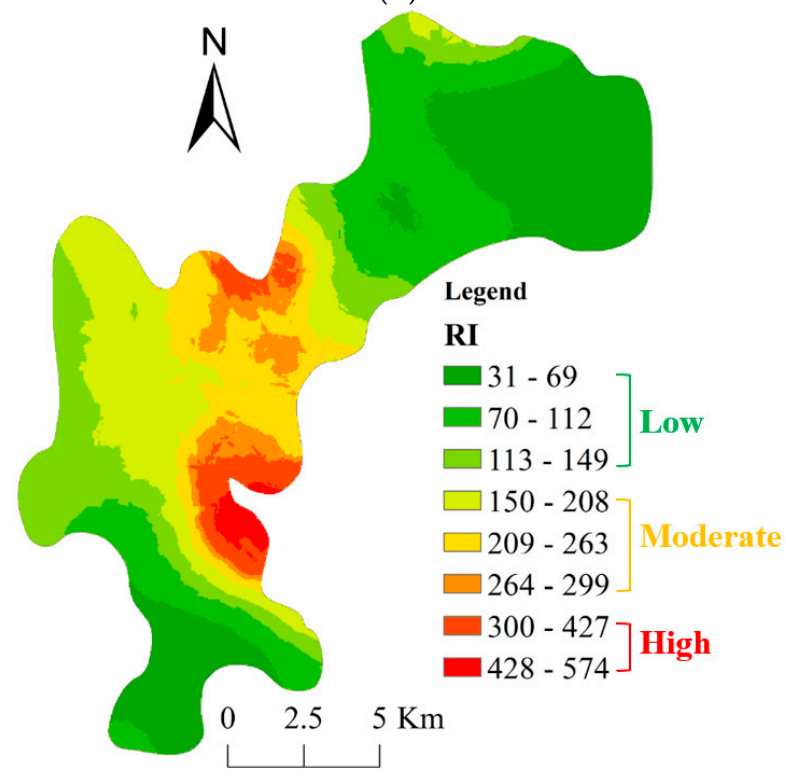

(c)

Figure 3. (a) Geoaccumulation index $\left(I_{g e o}\right)$ of each heavy metal in regional soils, (b) levels of $E_{i}$, and (c) the spatial distribution and levels of the RI.

\subsection{Source Identification and Apportionment By PCA/APCS}

The PCA results obtained by applying varimax rotation to the concentrations of heavy metals in the soil are shown in Table 6. Three principal components (PCs) with eigenvalues higher than 1 (before and after rotation) were extracted; PCA led to a reduction in the initial dimension of the dataset to three components that explain $87.21 \%$ of the data variation. The first PC (PC1) explains $38.98 \%$ of the total variance and with high loadings for $\mathrm{Cd}, \mathrm{Mn}, \mathrm{Zn}$, and $\mathrm{Pb}$. As shown in Figure 2, the hot spots of $\mathrm{Cd}, \mathrm{Mn}, \mathrm{Zn}$, and $\mathrm{Pb}$ were all located in the southeastern part of the study area, where many mines and smelters of gold, silver, copper, iron, molybdenum, and sulfur, among other minerals, are located. Thus, PC1 can be considered a source of mineral exploitation and smelting involving a variety of minerals (ES_M). The second PC (PC2), dominated by $\mathrm{Co}$ and $\mathrm{Cu}$ and moderately by Cd, accounts for $25.74 \%$ of the total variance. As shown in Figure 2, the concentrations of $\mathrm{Co}$ and $\mathrm{Cu}$ have similar spatial distribution patterns characterized by an increasing accumulation from the north and south to the center of the study area. The only hot spot is located in the central part of the study area, where the oldest in-use copper mine (Tonglu Mountain Copper Mine) in China, with related tailings and smelters, is located. Cobalt (Co) resources are mostly associated with copper deposits. 
Thus, PC2 is mainly related to the mining exploitation and smelting of copper ore (ES_C). The third PC (PC3) is strongly correlated with $\mathrm{Cr}$ and Ni. The concentrations of $\mathrm{Cr}$ and $\mathrm{Ni}$ were lower than or approximately equal to their background values in Hubei soil, indicating that these elements mainly originate from natural sources.

Next, the APCS receptor model was applied to the three extracted components to quantify the contributions of the sources to each spatial grid. SPSS software was used to develop suitable programs and outputs for carrying out the apportionment procedure. The results of the statistical analysis are presented in Table 7 . The high values of $R^{2}$ for all heavy metals demonstrate that the source apportionment results meet the modeling requirements. Figure 4 shows the spatial distributions of various heavy metal concentrations that resulted from the three major sources. Notably, in the results of the source apportionment based on APCS, the source contribution estimates are not constrained to be non-negative $[26,37,38]$. Thus, the negative values in the results of the APCS source apportionment, including the negative values in Figure 4, indicate relatively small contributions. Furthermore, the contributions from non-specified sources (the forth to eighth components in Table 6) were negligible because the estimated values of $b_{0}$ in Equation (5) were usually very small. Based on the percentage of individual heavy metals apportioned to each source (Table 7), the fraction of the contribution of each source to the total heavy metal concentration in soils was estimated (see the last line in Table 7).

Table 6. Principal component analysis (PCA) results for the heavy metal concentrations $(\mathrm{mg} / \mathrm{kg}$ ) in the study area.

\begin{tabular}{|c|c|c|c|c|c|c|c|c|c|}
\hline \multirow{2}{*}{ Component } & \multicolumn{3}{|c|}{ Initial Eigenvalues } & \multicolumn{3}{|c|}{ Extraction Sums of Squared Loadings } & \multicolumn{3}{|c|}{ Rotation Sums of Squared Loadings } \\
\hline & Total & $\%$ of Variance & Cumulative \% & Total & $\%$ of Variance & Cumulative \% & Total & $\%$ of Variance & Cumulative \% \\
\hline 1 & 4.58 & 57.21 & 57.21 & 4.58 & 57.21 & 57.21 & 3.12 & 38.98 & 38.98 \\
\hline 2 & 1.25 & 15.68 & 72.89 & 1.25 & 15.68 & 72.89 & 2.06 & 25.74 & 64.72 \\
\hline 3 & 1.15 & 14.32 & 87.21 & 1.15 & 14.32 & 87.21 & 1.80 & 22.50 & 87.21 \\
\hline 4 & 0.33 & 4.09 & 91.31 & & & & & & \\
\hline 5 & 0.30 & 3.72 & 95.02 & & & & & & \\
\hline 6 & 0.22 & 2.80 & 97.82 & & & & & & \\
\hline 7 & 0.11 & 1.42 & 99.24 & & & & & & \\
\hline 8 & 0.06 & 0.77 & 100.00 & & & & & & \\
\hline \multirow{2}{*}{ Metal } & \multicolumn{3}{|c|}{ Component Matrix } & \multicolumn{3}{|c|}{ Rotated Component Matrix } & \multicolumn{3}{|c|}{ Component Scores Matrix } \\
\hline & PC1 & PC2 & PC3 & PC1 & PC2 & PC3 & PC1 & PC2 & PC3 \\
\hline $\mathrm{Cd}$ & 0.95 & 0.02 & -0.04 & 0.74 & 0.47 & 0.36 & 0.18 & 0.10 & 0.05 \\
\hline Co & 0.65 & 0.54 & 0.40 & 0.13 & 0.89 & 0.24 & -0.19 & 0.53 & 0.06 \\
\hline $\mathrm{Cr}$ & 0.70 & -0.20 & 0.57 & 0.21 & 0.40 & 0.81 & -0.17 & 0.13 & 0.50 \\
\hline $\mathrm{Cu}$ & 0.63 & 0.67 & 0.08 & 0.30 & 0.87 & -0.07 & -0.04 & 0.52 & -0.21 \\
\hline $\mathrm{Mn}$ & 0.78 & -0.04 & -0.44 & 0.87 & 0.20 & 0.04 & 0.37 & -0.08 & -0.18 \\
\hline $\mathrm{Ni}$ & 0.50 & -0.63 & 0.48 & 0.21 & -0.08 & 0.91 & -0.08 & -0.20 & 0.63 \\
\hline $\mathrm{Pb}$ & 0.81 & -0.25 & -0.41 & 0.93 & 0.06 & 0.21 & 0.40 & -0.20 & -0.06 \\
\hline $\mathrm{Zn}$ & 0.92 & -0.11 & -0.24 & 0.87 & 0.29 & 0.29 & 0.30 & -0.04 & -0.01 \\
\hline
\end{tabular}

Note: Factor loading values $>0.50$ are in bold.

Table 7. Estimated average source contributions (\%) of heavy metals.

\begin{tabular}{ccccc}
\hline Heavy Metal & ES_M & ES_C & Natural Sources & $\mathbf{R}^{\mathbf{2}}$ \\
\hline $\mathrm{Cd}$ & 51.97 & 28.45 & 19.58 & 0.94 \\
$\mathrm{Co}$ & 4.69 & 79.65 & 15.67 & 0.99 \\
$\mathrm{Cr}$ & 7.31 & 25.89 & 66.80 & 0.99 \\
$\mathrm{Cu}$ & 45.99 & 83.40 & -29.39 & 0.94 \\
$\mathrm{Mn}$ & 82.69 & 16.63 & 0.71 & 0.99 \\
$\mathrm{Ni}$ & 19.89 & -9.56 & 89.67 & 0.99 \\
$\mathrm{~Pb}$ & 70.95 & 2.33 & 26.73 & 0.94 \\
$\mathrm{Zn}$ & 69.83 & 14.86 & 15.31 & 0.98 \\
Total & 69.21 & 23.17 & 7.62 &
\end{tabular}

ES_M: Mineral exploitation and smelting involving a variety of minerals; ES_C: Mining exploitation and smelting of copper ore. 


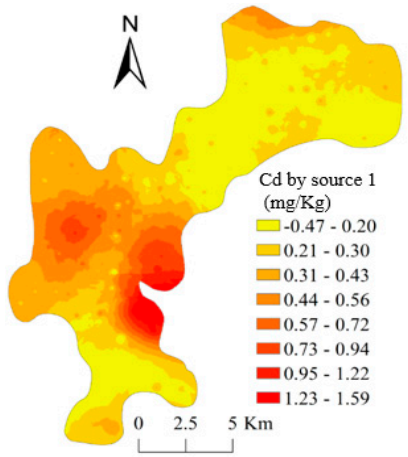

(a)

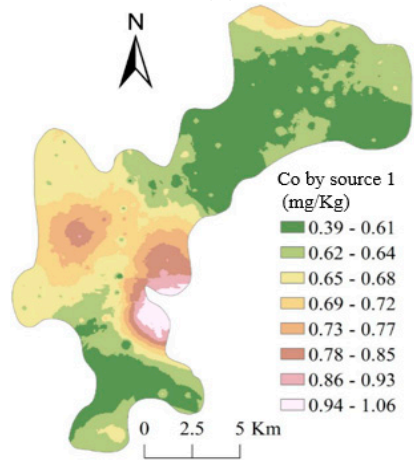

(d)

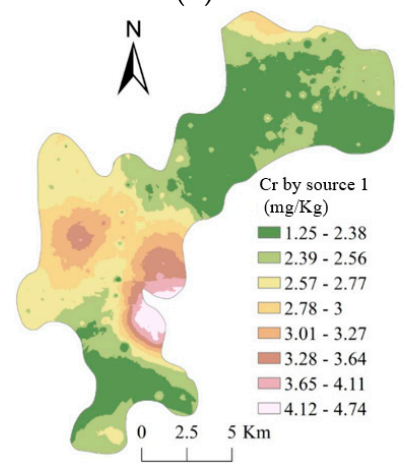

(g)

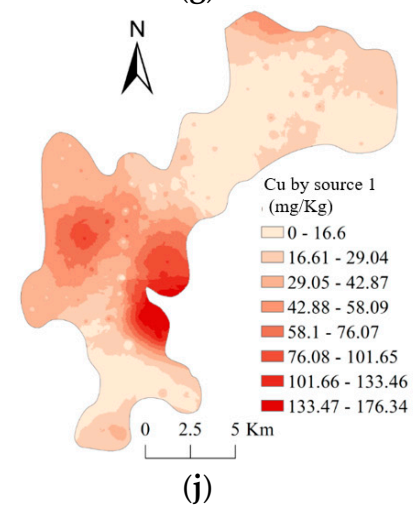

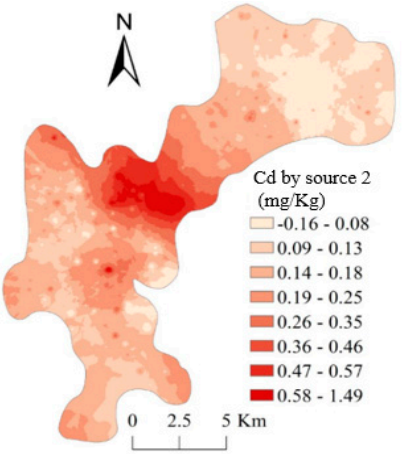

(b)

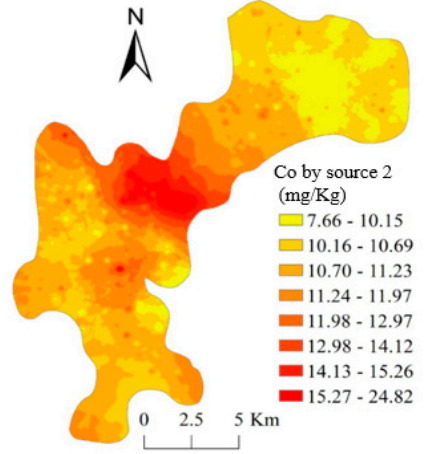

(e)

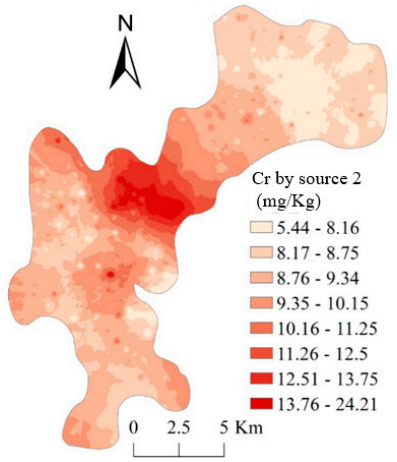

(h)

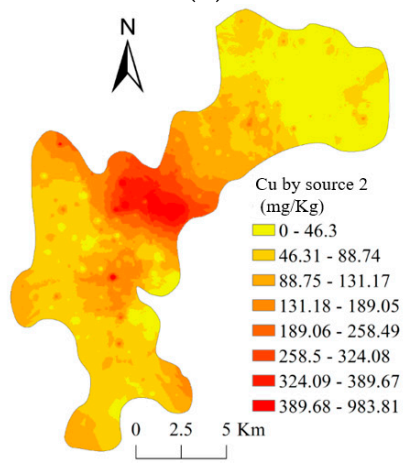

(k)

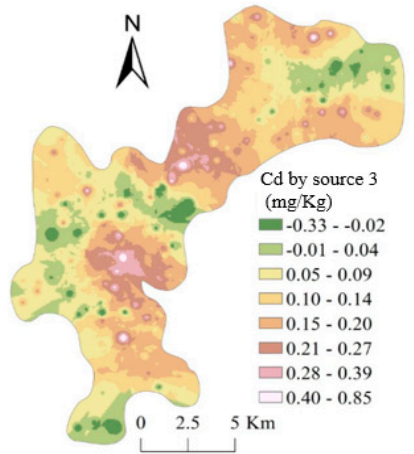

(c)

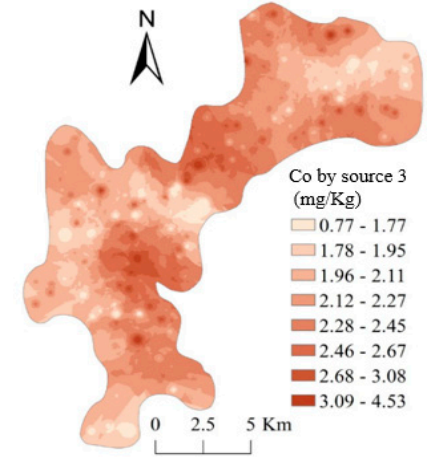

(f)

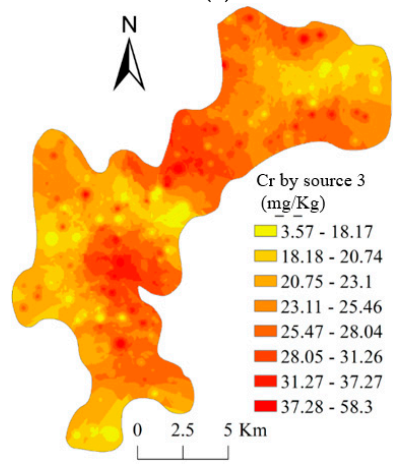

(i)

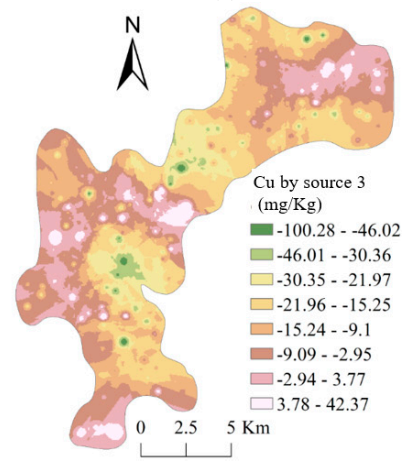

(1)

Figure 4. Cont. 


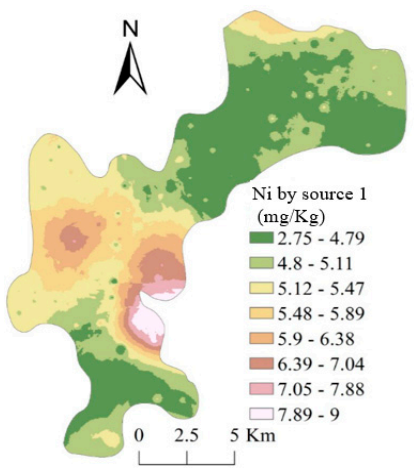

(m)

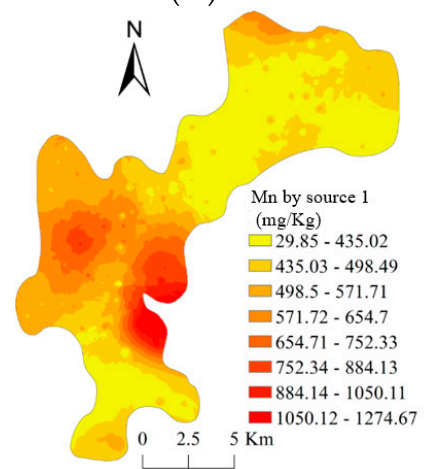

(p)

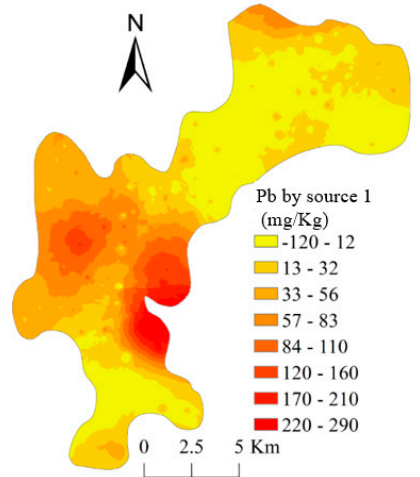

(s)

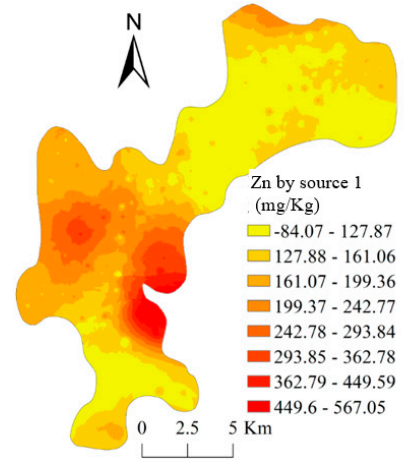

(v)

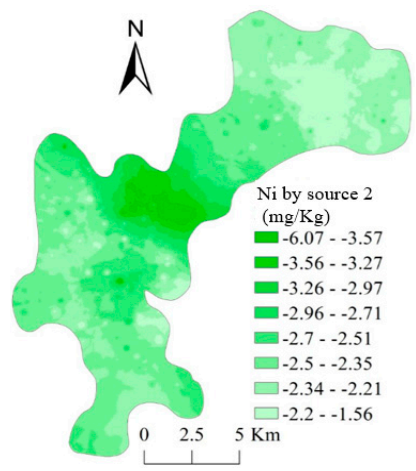

(n)

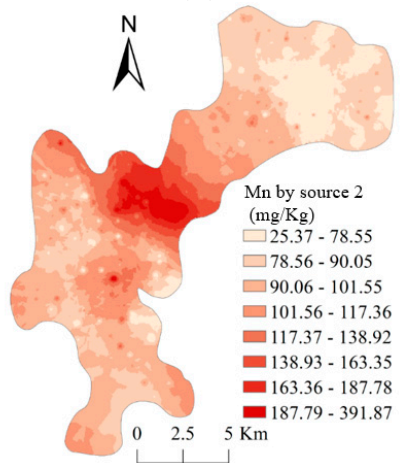

(q)

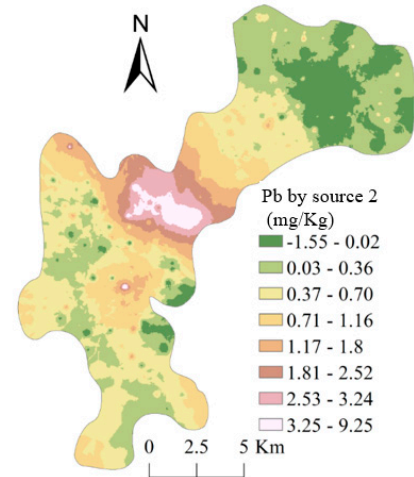

(t)

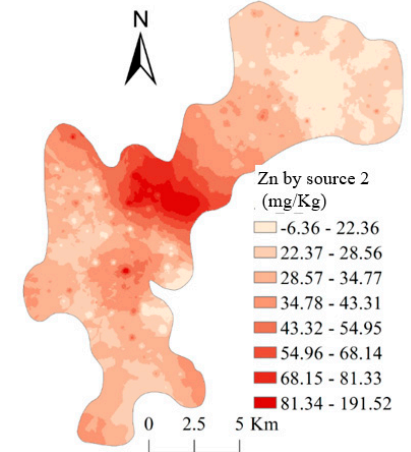

(w)

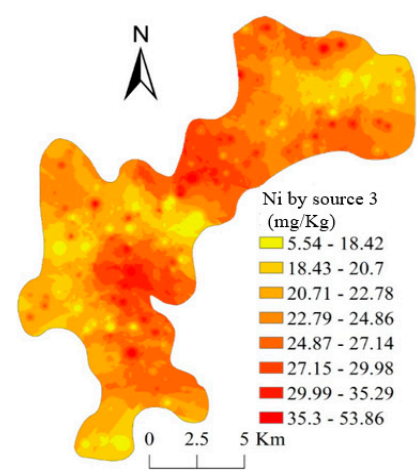

(o)

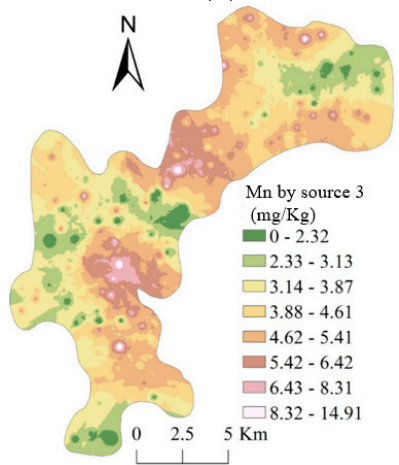

(r)

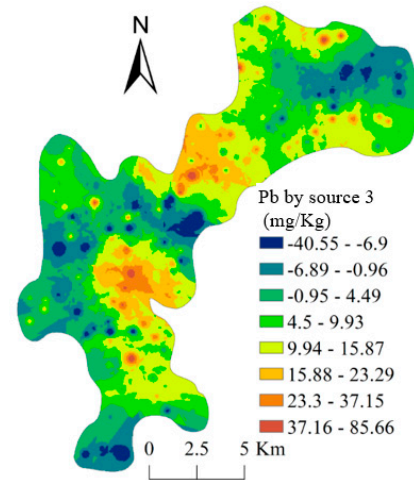

(u)

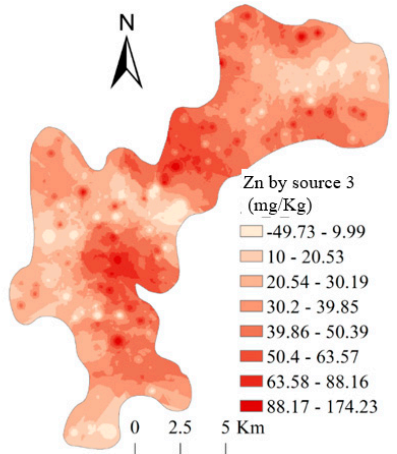

(x)

Figure 4. Contribution maps of the major sources of soil heavy metals: (a) Cd by source 1 ; (b) Cd by source 2; (c) Cd by source 3; (d) Co by source 1; (e) Co by source 2; (f) Co by source 3; (g) Cr by source $1 ;(\mathbf{h})$ Cr by source $2 ;(\mathbf{i})$ Cr by source 3 ; (j) Cu by source $1 ;(\mathbf{k})$ Cu by source 2 ; (l) Cu by source 3 ; (m) Ni by source $1 ;$ (n) Ni by source 2; (o) Ni by source 3; (p) Mn by source 1; (q) Mn by source 2; (r) Mn by source 3; (s) Pb by source 1; (t) Pb by source 2; (u) Pb by source 3; (v) Zn by source 1; (w) Zn by source 2; and (x) Zn by source 3. Source 1: ES_M; Source 2: ES_C; Source 3: Natural sources. 
According to the results in Table 7 and Figure 4, in Daye City, ES_M accounted for an average of $51.97 \%, 82.69 \%, 70.95 \%$, and $69.83 \%$ of $\mathrm{Cd}, \mathrm{Mn}, \mathrm{Pb}$, and $\mathrm{Zn}$, respectively. The high contributions made by the ES_M source were located in the western and southeastern parts of the study area, where various kinds of mines and smelters are distributed. The ES_M source contributed $69.21 \%$ of the total soil heavy metals in the study area. Therefore, ES_M is the largest source of soil heavy metal pollution in Daye. On the other hand, ES_C accounted for an average of $79.65 \%$ and $83.4 \%$ of the Co and $\mathrm{Cu}$, respectively. The hotspots of the contributions by ES_C are located in the western and central parts of the study area, which have a long history of copper mining and related smelting enterprises. This again indicates that the second greatest source of heavy metal pollution was directly related to the mining and smelting of copper.

Meanwhile, as is shown in Figure 4, the high contributions for all heavy metals by source 1 and source 2 were located in or around the mines and smelters (also refer to the spatial distributions of land cover in Figure 1). It is worth noting that there are the same spatial distribution patterns of contribution maps for all heavy metals from the same source. For example, Figure $4 a, d, g, j, m, p, s, v$ shows spatial distributions of the various heavy metals' concentrations contributed by ES_M. Those maps clearly point out three locations of ES_M sources (the north, west, and southeast parts of the study area) and four kinds of heavy metals mainly contributed by the ES_M source (Cd, $\mathrm{Mn}, \mathrm{Pb}$, and $\mathrm{Zn})$. Similarly, Figure $4 b, e, h, k, n, q, t, w$ indicates that ES_C is located in the center of the study area, and it is mainly responsible for the accumulations of $\mathrm{Cu}$ and $\mathrm{Co}$. In addition, as is shown in Figure 4j, ES_M also contributed $\mathrm{Cu}$ to the soil. In addition, a part of $\mathrm{Cd}, \mathrm{Mn}$, and $\mathrm{Zn}$ in the soils were contributed by ES_C, as shown in Figure $4 b, q, w$; thus, the contribution maps of the identified sources of heavy metals might be a powerful tool to analyze the land covers that contaminate surrounding soils.

\section{Conclusions}

The present study identified the pollutant characteristics and sources of heavy metals in soils of Daye, China. It was based on a spatial distribution analysis, pollution assessment, and PCA/APCS methods. There are two main conclusions:

(1) The soils in Daye are seriously polluted by the heavy metals, $\mathrm{Cd}, \mathrm{Cu}, \mathrm{Pb}$, and $\mathrm{Zn}$. The mean concentrations of $\mathrm{Cd}, \mathrm{Cu}, \mathrm{Pb}$, and $\mathrm{Zn}$ were higher than the corresponding background values, with the mean concentration of $\mathrm{Cd}$ being almost seven times more than the background value. The results of the correlation analysis showed that $\mathrm{Cd}, \mathrm{Mn}, \mathrm{Pb}$, and $\mathrm{Zn}$ have a high significant positive relationship with each other. In addition, the correlation between $\mathrm{Cu}$ and $\mathrm{Co}$ was highly significant and positive. The $I_{\text {geo }}$ results showed that the contamination levels ranged from no pollution $(\mathrm{Co}, \mathrm{Cr}, \mathrm{Mn}$, and $\mathrm{Ni})$ to moderate contamination $(\mathrm{Cd}, \mathrm{Cu}, \mathrm{Pb}$, and $\mathrm{Zn})$ and heavy contamination $(\mathrm{Cd}, \mathrm{Cu}$, and $\mathrm{Pb})$. More than $90 \%$ of the study area was polluted by at least one kind of heavy metal, and the accumulation of $\mathrm{Cd}$ posed the most potential ecological risk among all kinds of heavy metals; and

(2) There were three main factors influencing the concentrations of soil heavy metals: ES_M, ES_C, and natural sources. Among these sources, ES_M was foremost, explaining 57.21\% of the total variance. The APCS showed that $69.21 \%$ and $23.17 \%$ of the heavy metal concentrations were ascribed to ES_M and ES_C, respectively. Those sources were significantly related to the mines and smelters scattered in the study area.

Based on this study, we suggest a few steps to be taken to solve this serious polluted soil issue: (1) Soil remediation is urgently needed in Dye; (2) mines and smelters in the studied area should be controlled strictly to prevent further pollution of heavy metals in the soils; (3) the concentration of heavy metal in local agricultural products should be strictly detected before entering the market; and (4) local residents should avoid direct contact with soils in heavily polluted area as far as possible.

Author Contributions: Formal analysis, X.Y.; Investigation, Y.L.; Methodology, Y.Y.; Validation, X.T.; Visualization, X.Y.; Writing—original draft, L.H.; Writing—review \& editing, L.H. and Y.Y. 
Funding: This research was funded by the National Science Foundation of China (Grant No. 41671217, 41601280, and 41877001), and a project supported by the Fundamental Research Funds for the Central Universities (Grant No. 2662017PY038).

Conflicts of Interest: The authors declare no conflicts of interest.

\section{References}

1. Guo, G.H.; Wu, F.C.; Xie, F.Z.; Zhang, R.Q. Spatial distribution and pollution assessment of heavy metals in urban soils from southwest China. J. Environ. Sci. 2012, 24, 410-418. [CrossRef]

2. Chen, T.B.; Zheng, Y.M.; Lei, M.; Huang, Z.C.; Wu, H.T.; Chen, H.; Fan, K.K.; Yu, K.; Wu, X.; Tian, Q.Z. Assessment of heavy metal pollution in surface soils of urban parks in Beijing, China. Chemosphere 2005, 60, 542-551. [CrossRef] [PubMed]

3. Wang, Q.Y.; Zhang, J.B.; Zhao, B.Z.; Xin, X.L.; Zhang, C.Z.; Zhang, H.L. The influence of long-term fertilization on cadmium (Cd) accumulation in soil and its uptake by crops. Environ. Sci. Pollut. Res. 2014, 21, 10377-10385. [CrossRef] [PubMed]

4. Xiao, R.; Wang, S.; Li, R.; Wang, J.J.; Zhang, Z. Soil heavy metal contamination and health risks associated with artisanal gold mining in Tongguan, Shanxi, China. Ecotoxicol. Environ. Saf. 2017, 141, 17-24. [CrossRef] [PubMed]

5. Dong, J.; Yang, Q.W.; Sun, L.N.; Zeng, Q.; Liu, S.J.; Pan, J.; Liu, X.L. Assessing the concentration and potential dietary risk of heavy metals in vegetables at a $\mathrm{Pb} / \mathrm{Zn}$ mine site, China. Environ. Earth Sci. 2011, 64, 1317-1321. [CrossRef]

6. Zhang, X.W.; Yang, L.S.; Li, Y.H.; Li, H.R.; Wang, W.Y.; Ye, B.X. Impacts of lead/zinc mining and smelting on the environment and human health in China. Environ. Monit. Assess. 2012, 184, 2261-2273. [CrossRef] [PubMed]

7. Hu, R.Z.; Liu, J.M.; Zhai, M.G. Mineral Resources Science in China: A Roadmap to 2050; Science Press: Beijing, China, 2009.

8. Liang, J.; Feng, C.; Zeng, G.; Gao, X.; Zhong, M.; Li, X.; Li, X.; He, X.; Fang, Y. Spatial distribution and source identification of heavy metals in surface soils in a typical coal mine city, Lianyuan, China. Environ. Pollut. 2017, 225, 681-690. [CrossRef] [PubMed]

9. Wang, F.; Huang, Y.; Wang, X.; Gao, Z.; Yu, F.; Xu, F.; Bao, Q.; Hu, Y.; Qiao, M.; Jin, S.; et al. Ecological risk assessment of heavy metals in surrounding soils of tungsten ores: Comparison of different evaluation methods. Environ. Chem. 2015, 34, 225-233. (In Chinese)

10. Xu, D.M.; Yan, B.; Chen, T.; Lei, C.; Lin, H.Z.; Xiao, X.M. Contaminant characteristics and environmental risk assessment of heavy metals in the paddy soils from lead $(\mathrm{Pb})$-zinc $(\mathrm{Zn})$ mining areas in Guangdong Province, South China. Environ. Sci. Pollut. Res. 2017, 24, 24387-24399. [CrossRef] [PubMed]

11. Chen, H.; Ouyang, J.; Ma, Z. Status quo of and countermeasures for Cd contamination of farmland in the vicinity of Daye smeltery. Soils 2003, 82, 76-79. (In Chinese)

12. Song, Q.; Qi, S.; Zhang, B.; Chen, W.; Xia, L.; Wang, X.; Zhang, X.; Zhang, J. Distribution characteristics and pollution assessment of heavy metals in the soil around Tonglu mountain area in Daye. Environ. Chem. 2011, 30, 1672-1673. (In Chinese)

13. Du, P.; Xie, Y.; Wang, S.; Zhao, H.; Zhang, Z.; Wu, B.; Li, F. Potential sources of and ecological risks from heavy metals in agricultural soils, Daye City, China. Environ. Sci. Pollut. Res. 2015, 22, 3498-3507. [CrossRef] [PubMed]

14. Du, P.; Zhao, H.; Wang, S.; Zhang, Z.; Li, H.; Han, C.; Wu, B.; Li, F. Spatial distribution and assessment of Cadmium pollution in farmland soils, Daye City. Soils 2015, 45, 1028-1035. (In Chinese)

15. Sun, Q.; Yin, C.; Deng, J.; Xiong, Q. Investigation on the heavy metal contamination of farmland soil and brassica campestris nearby mining areas in Daye City, China areas in Daye City, China. J. Agro-Environ. Sci. 2012, 31, 85-91. (In Chinese)

16. Yang, J.; Ma, S.; Li, W. Heavy metal pollution of food and its influence on the health risk of the local population in Daye mining area. Environ. Sci. Technol. 2017, 40, 249-255. (In Chinese)

17. Yang, Y.; Zhang, C.T.; Zhang, R.X. BME prediction of continuous geographical properties using auxiliary variables. Stoch. Environ. Res. Risk Assess. 2016, 30, 9-26. [CrossRef]

18. Men, C.; Liu, R.; Xu, F.; Wang, Q.; Guo, L.; Shen, Z. Pollution characteristics, risk assessment, and source apportionment of heavy metals in road dust in Beijing, China. Sci. Total Environ. 2018, 612, 138-147. [CrossRef] [PubMed] 
19. Pathak, A.K.; Kumar, R.; Kumar, P.; Yadav, S. Sources apportionment and spatiotemporal changes in metal pollution in surface and sub-surface soils of a mixed type industrial area in India. J. Geochem. Explor. 2015, 159, 169-177. [CrossRef]

20. Kusin, F.M.; Rahman, M.S.; Madzin, Z.; Jusop, S.; Mohamat-Yusuff, F.; Ariffin, M.; Ms, Z. The occurrence and potential ecological risk assessment of bauxite mine-impacted water and sediments in Kuantan, Pahang, Malaysia. Environ. Sci. Pollut. Res. 2016, 24, 1-16. [CrossRef] [PubMed]

21. Mamat, Z.; Haximu, S.; Zhang, Z.Y.; Aji, R. An ecological risk assessment of heavy metal contamination in the surface sediments of Bosten Lake, northwest China. Environ. Sci. Pollut. Res. 2016, 23, 7255-7265. [CrossRef] [PubMed]

22. Xu, Z.Q.; Ni, J.; Tuo, X.G.; Zhang, C.J. Calculation of heavy metals' toxicity coefficient in the evaluation of potential ecological risk index. China Environ. Sci. Technol. 2008, 31, 112-115. (In Chinese)

23. Thurston, G.D.; Spengler, J.D. A quantitative assessment of source contributions to inhalable particulate matter pollution in metropolitan Boston. Atmos. Environ. 1985, 19, 9-25. [CrossRef]

24. Song, Y.; Xie, S.; Zhang, Y.; Zeng, L.; Salmon, L.G.; Zheng, M. Source apportionment of PM2.5 in Beijing using principal component analysis/absolute principal component scores and UNMIX. Sci. Total Environ. 2006, 327, 278-286. [CrossRef] [PubMed]

25. Jain, S.; Sharma, S.K.; Choudhary, N.; Masiwal, R.; Saxena, M.; Sharma, A.; Mandal, T.K.; Gupta, A.; Gupta, N.C.; Sharma, C. Chemical characteristics and source apportionment of $\mathrm{PM}_{2.5}$ using PCA/APCS, UNMIX, and PMF at an urban site of Delhi, India. Environ. Sci. Pollut. Res. 2017, 24, 14637-14656. [CrossRef] [PubMed]

26. Guo, H.; Wang, T.; Louie, P.K.K. Source apportionment of ambient non-methane hydrocarbons in Hong Kong: Application of a principal component analysis/absolute principal component scores (PCA/APCS) receptor model. Environ. Pollut. 2004, 129, 489-498. [CrossRef] [PubMed]

27. Meng, L.; Zuo, R.; Wang, J.; Yang, J.; Teng, Y.; Zhai, Y.; Shi, R. Quantitative source apportionment of groundwater pollution based on PCA-APCS-MLR. China Environ. Sci. 2017, 37, 3773-3786.

28. China National Environmental Monitoring Center (CNEMC). The Background Centrations of Soil Elements of China; China Environmental Science Press: Beijing, China, 1990.

29. Tian, M.L.; Zhong, X.M.; Zhagn, Y.X.; Yu, Y.Y.; Pang, R.; Zhou, L.; Song, B. Concentrations and health risk assessments of heavy metal contents in soil and rice of mine contaminated areas. Environ. Sci. 2018, 39, 2919-2926. (In Chinese)

30. Chu, B.B.; Luo, L.Q. Evaluation of heavy metal pollution in soils from nanjing qixiashang lead-zinc mines. Rock Miner. Anal. 2010, 29, 5-846. (In Chinese)

31. Zhou, Y.; Chen, Q.; Deng, S.P.; Wan, J.Z.; Zhang, S.T.; Long, T.; Li, Q.; Lin, Y.S.; Wu, Y.J. Principal component analysis and ecological risk assessment of heavy metals in farmland soils around a $\mathrm{Pb}-\mathrm{Zn}$ mine in southwestern china. Environ. Sci. 2018, 39, 2884-2893. (In Chinese)

32. Chen, C.H.; Ni, S.J.; He, B.B.; Zhang, C.J. Heavy metals contamination of soils of in Dexing mine, Jiangxi province, China. Earth Environ. 2007, 35, 134-141. (In Chinese)

33. Lu, S.J.; Wang, Y.Y.; He, L.H. Heavy metal pollution and ecological risk assessment of the paddy soils around a Pb-Zn mine in Huize country. Ecol. Environ. Sci. 2014, 23, 1832-1838. (In Chinese)

34. Liu, D.L.; Wang, K.F.; Yang, Q.H.; Zhu, Q. Assessment and correlation analysis of heavy metals pollution in northeastern Guangdong Ag-Sb deposit. J. Northwest For. Univ. 2015, 30, 65-70. (In Chinese)

35. Li, J.K.; Zhang, D.; Zhou, P.; Liu, Q.L. Assessment of Heavy Metal Pollution in Soil and Its Bioaccumulation by Dominant Plants in a Lead-Zinc Mining Area, Nanjing. Environ. Sci. 2018, 39, 3845-3853. (In Chinese)

36. Xie, R.X.; Tian, D.L.; Fang, X. Assessment of Pollution of Heavy Metals on the Slag Wasteland of Xiangtan Manganese Mine. J. Cent. South. For. Univ. 2005, 25, 38-41. (In Chinese)

37. Harrison, R.M.; Smith, D.J.T.; Luhana, L. Source apportionment of atmospheric polycyclic aromatic hydrocarbons collected from an urban location in Birmingham, U.K. Environ. Sci. Technol. 1996, 30, 825-832. [CrossRef]

38. Miller, S.L.; Anderson, M.J.; Daly, E.P.; Milford, J.B. Source apportionment of exposures to volatile organic compounds. I. Evaluation of receptor models using simulated exposure data. Atmos. Environ. 2002, 36, 3629-3641. [CrossRef]

(C) 2018 by the authors. Licensee MDPI, Basel, Switzerland. This article is an open access article distributed under the terms and conditions of the Creative Commons Attribution (CC BY) license (http://creativecommons.org/licenses/by/4.0/). 